\title{
MECANISMO DAS
}

\section{VACINAS DE}

\section{COVID-19}

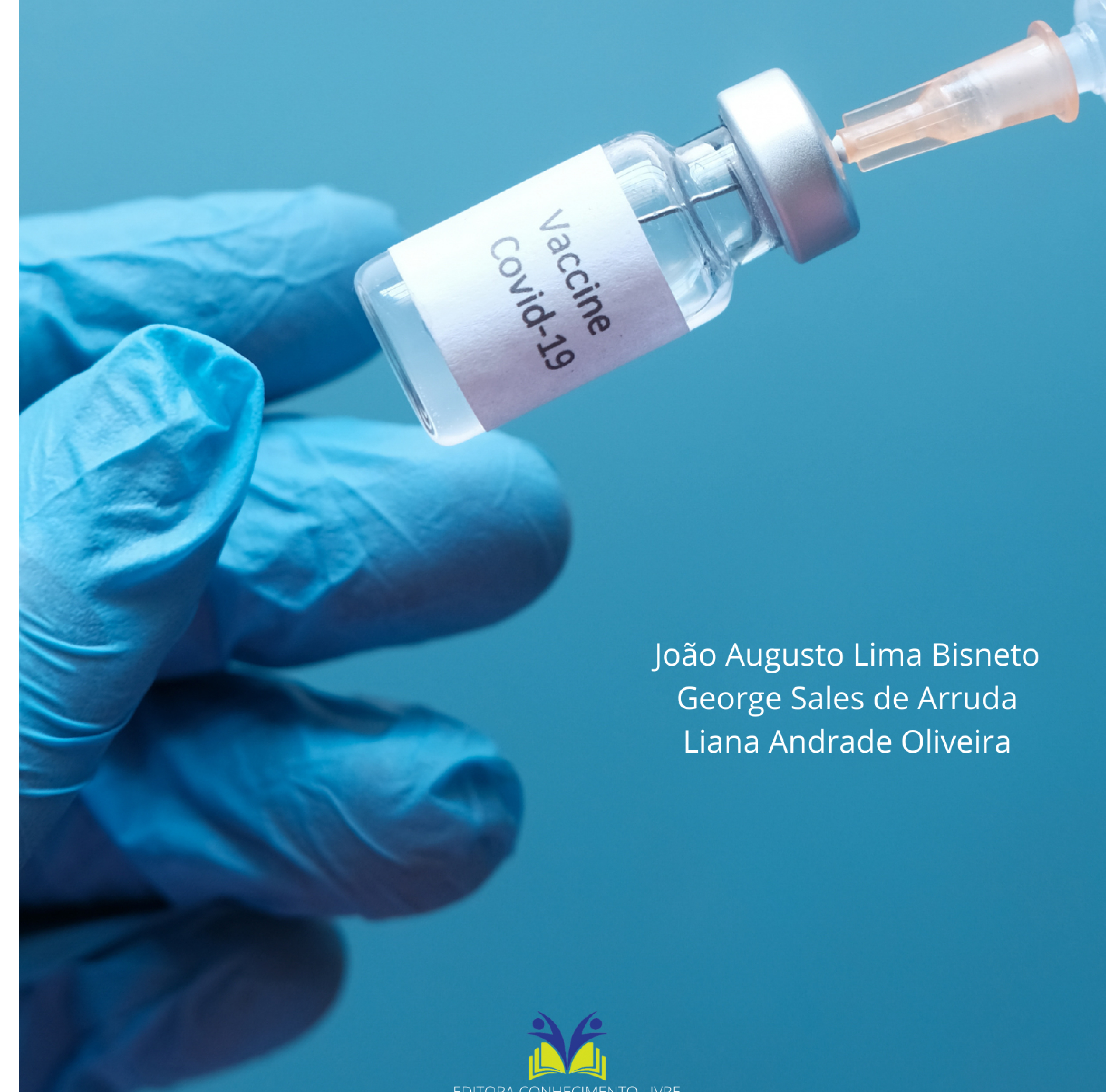


João Augusto Lima Bisneto

George Sales de Arruda

Liana Andrade Oliveira

Mecanismo das vacinas de COVID-19

$1^{\text {a }}$ ed.

Piracanjuba-GO

Editora Conhecimento Livre

Piracanjuba-GO 
$1^{\mathrm{a}} \mathrm{ed}$

\section{Dados Internacionais de Catalogação na Publicação (CIP)}
B319M Mecanismo das vacinas de COVID-19

/ João Augusto Lima Bisneto. George Sales de Arruda. Liana Andrade Oliveira. - Piracanjuba-GO

Editora Conhecimento Livre, 2021

17 f.: il

DOI: $10.37423 / 2021$.edcl 378

ISBN: 978-65-89955-93-1

Modo de acesso: World Wide Web

Incluir Bibliografia

1. vacina 2. covid-19 3. atenuada 4. inativada 5. rna I. Bisneto, João Augusto Lima II. Arruda,

George Sales de III. Oliveira, Liana Andrade IV. Título

CDU: 613

https://doi.org/10.37423/2021.edc1378

O conteúdo dos artigos e sua correção ortográfica são de responsabilidade exclusiva dos seus respectivos autores. 


\title{
EDITORA CONHECIMENTO LIVRE
}

\section{Corpo Editorial}

\author{
Dr. João Luís Ribeiro Ulhôa \\ Dra. Eyde Cristianne Saraiva-Bonatto \\ Dr. Anderson Reis de Sousa \\ MSc. Frederico Celestino Barbosa \\ MSc. Carlos Eduardo de Oliveira Gontijo
}

$\underline{\text { MSc. Plínio Ferreira Pires }}$

Editora Conhecimento Livre

Piracanjuba-GO 
CAPÍTULO 1 5

VACINA DE VÍRUS INATIVADO João Augusto Lima Bisneto George Sales de Arruda Liana Andrade Oliveira DOI 10.37423/211105015

CAPÍTULO 2 8

VACINA VIRAL NÃO REPLICANTE

Liana Andrade Oliveira

George Sales de Arruda

João Augusto Lima Bisneto

DOI 10.37423/211105017

CAPÍTULO 3

VACINAS DE RNA

George Sales de Arruda

João Augusto Lima Bisneto

Liana Andrade Oliveira

DOI 10.37423/211105018 


\section{Capítulo 1}

doi $10.37423 / 211105015$

\section{VACINA DE VÍRUS INATIVADO}


As vacinas inativadas contêm vírus que, em decorrência de tratamento com radiação, calor ou produtos químicos, não podem se replicar. É um método seguro e com ampla utilização prévia (1). Contêm um repertório completo de componentes imunogênicos do vírus original e, em comparação com vírus atenuados, não apresentam risco de reativação viral se devidamente inativados. Os epítopos imunogênicos do vírus podem ser estruturalmente deformados durante o processo de inativação, o que pode prejudicar a proteção que eles podem fornecer (2). Tendem a produzir uma resposta imune mais fraca do que as vacinas vivas atenuadas - portanto, os adjuvantes são necessários para fornecer uma resposta imune eficaz (3). Quando introduzidas no hospedeiro, induzem produção de anticorpos protetores contra a glicoproteína hemaglutinina na superfície do vírus (4).

A vacina dessa classe usada no Brasil é denominada Coronavac, também conhecida como PiCoVacc, desenvolvida pelo laboratório Chinês Sinovac, em parceria com o Instituto Butantan. É composta pelo vírus SARS-CoV-2 extraído de uma cepa de um paciente, cultivado em células Vero, inativado com $\beta$ propionolactona, purificado e adsorvido em hidróxido de alumínio. É ideal que se conserve a vacina entre 2 e 8 ㅇ C e que seja administrada por via intramuscular, utilizando seringas individuais de $0,5 \mathrm{~mL}$. No nosso país, é produzida em frascos com 10 doses. Os estudos nacionais realizados pelo Instituto Butantan em 17 centros de pesquisas com 12.000 voluntários demonstraram uma eficácia total de 50,39\% (IC95: 35,26-61,98\%), não há dados concretos ainda de eficácia por idade e por condições clínicas associadas (5). A maioria dos eventos adversos foram leves, caracterizados principalmente por dor no local da aplicação e cefaleia. Pesquisadores chegaram à conclusão de que é necessária uma dose de reforço para gerar uma resposta imunológica adequada. Também foi constatado que um intervalo mais longo, de 21 a 28 dias entre a primeira dose e a dose de reforço, gera títulos de anticorpos mais altos se comparado ao grupo de intervalo mais curto com 14 dias (6). 


\section{REFERÊNCIAS BIBLIOGRÁFICAS:}

(1) Sociedade Brasileira de Pediatria. Vacinas COVID-19 - atualização. Soc Bras. Pediatr. 2021; 12.

(2) Li YD, Chi WY, Su JH, Ferrall L, Hung CF, Wu TC. Coronavirus vaccine development: from SARS and MERS to COVID-19. J Biomed Sci. 2020; 27(1): 104.

(3) A. Kumar , TS Meldgaard, S. Bertholet. Novas plataformas para o desenvolvimento de uma vacina universal contra influenza Frente. Immunol. 9 ( 2018 ), 1 - 14.

(4) Rawat K, Kumari P, Saha L. COVID-19 vaccine: a recent update in pipeline vaccines, their design and development strategies. Eur J Pharmacol. 2021; 892: 173751.

(5) Sociedade Brasileira de Pediatria. Dúvidas sobre vacinas COVID-19 - perguntas e respostas. Soc Bras Pediatr. 2021; 13.

(6) Zhu, et al. Imunogenicidade e segurança de uma vacina COVID-19 com vetor de adenovírus tipo 5 recombinante em adultos saudáveis com 18 anos ou mais: um ensaio de fase 2 randomizado, duplocego, controlado por placebo, Lancet, 396 (2020), 479 - 488 


\section{Capítulo 2}

doi $10.37423 / 211105017$

\section{VACINA VIRAL NÃO REPLICANTE}

Liana Andrade Oliveira

George Sales de Arruda

Unichristus

João Augusto Lima Bisneto

Unichristus 
No desenvolvimento das vacinas de vetores virais, o gene antigênico de interesse é expresso a partir de outro micro-organismo, vírus ou bactéria. No caso das vacinas contra o SARS-CoV-2, é inserido apenas o gene que codifica a produção da proteína spike (S), responsável pela ligação viral com as células do organismo humano, geralmente, dentro de outro vírus modificado para que seja incapaz de se replicar e causar doença ou qualquer alteração no genoma (1). Esse vírus carreia o código genético que instrui a formação da proteína S e é, portanto, apenas um vetor da informação genética, com a finalidade de as células humanas passarem a fabricar a proteína $S$, e desencadear uma resposta imunológica contra o novo coronavírus. (2)

A longevidade da resposta imune gerada pela vacina depende do tipo de vetor viral utilizado (3), como as plataformas virais do vírus Vaccinia Ankara Modificado (MVA), da encefalite equina venezuelana (VEE) e do adenovírus (Ad) (4).

Os adenovírus (Ad) são os candidatos com vetor viral mais amplamente usados para vacina SARS-CoV2 não replicantes. São vírus de DNA de fita dupla que usualmente têm a replicação ineficaz por meio da deleção de sua região E1, essencial para a replicação (5). Esses vetores geralmente têm a região E3 não essencial deletada também, a fim de criar mais espaço para genes estranhos (6). Uma fita de expressão é então inserida com o transgene sob o controle de um promotor exógeno. Assim, os vetores virais são capazes de aceitar grandes inserções em seu genoma, fornecendo uma plataforma flexível para o projeto de antígenos (4).

As características dos adenovírus que são benéficas para esse fim incluem a infecção de células que estão ou não em divisão, os níveis exacerbados de transgenes, a capacidade de crescimento para títulos elevados in vitro, a escassa interação com genoma do hospedeiro e a estabilidade não só física, mas também genética (6).

Ademais, como os adenovírus têm como alvo as células epiteliais, eles são os principais candidatos a provocar uma resposta ou reação da mucosa, apresentando, assim, maior facilidade para atração de mediadores imunológicos com o fito de propiciar uma imunidade sistêmica (6).

Após a infecção das células hospedeiras, tornam-se evidentes altos níveis de expressão do transgene e sobrerregulação de moléculas coestimulatórias, as quais elicitam as respostas de citocinas e quimiocinas, aperfeiçoando a imunogenicidade (5). 
Em suma, esses vetores fornecem antígenos às células, mimetizando a infecção natural, de modo que induzem respostas imunes celulares e humorais específicas robustas, não necessitando de adjuvantes adicionais (4).

Em contrapartida, essa plataforma de vacina apresenta desvantagens, como apresentar um processo de fabricação mais complexo, que pode interferir na eficiência dos vetores virais, expressar um risco de interação genômica e manifestar uma resposta mais atenuada devido a uma imunidade préexistente contra o vetor (4).

Atualmente, as duas vacinas que mais se destacam nessa plataforma são a AstraZeneca - Universidade de Oxford (AZD1222) - e Janssen Pharmaceutical Companies - Johnson \& Johnson (Ad26COVS2):

- AstraZeneca - Universidade de Oxford:

A vacina AZD1222 é baseada em um adenovírus de DNA de chimpanzé (ChAdOx1) modificado, que não foi exposto a populações humanas, sendo assim, não gera uma resposta imune ao vírus, apenas à proteína viral spike codificada no DNA do hospedeiro (7).

O material viral é injetado em humanos e se liga às células hospedeiras. Em seguida, esse material é liberado no citoplasma e migra para o núcleo da célula. O DNA do vírus utiliza enzimas do hospedeiro para ser convertido em mRNA com o intuito de replicar proteínas spike. Diante disso, não é incorporado ao DNA celular, proporciona uma reação imunológica de célula T e induz anticorpos neutralizantes logo após a primeira dose da vacina, sendo reforçada após a segunda dose (7).

A OMS (Organização Mundial da Saúde) aponta eficácia de 63,09\% após a primeira dose e de 70,4\% após a segunda dose.

Outra vantagem da vacina se remete ao fato de que não necessita de armazenamentos complexos, como geladeiras com temperaturas extremamente frias - é o caso das vacinas mRNA. Portanto, é mais adequada para países de baixa e média renda (7).

Nesse contexto, estudos iniciais mostraram ser uma vacina segura e com alguns efeitos adversos leves, que incluem dor no local da injeção, vermelhidão, mialgias, artralgias e cefaleia. Eventos tromboembólicos e trombocitopenia foram relatados. No entanto, não foi constatada associação com a vacina, sendo necessários mais estudos sobre os casos (7).

- Janssen Pharmaceutical Companies - Johnson \& Johnson: 
A vacina denominada Ad26COV2S ou JNJ-78436725 apresenta como vantagem o fato de ter sua aplicação em dose única, bem como poder ser preservada em geladeira por vários meses sem necessidade de temperaturas extremamente frias, uma vez que não é derivada de mRNA (7).

Essa vacina faz uso de um vírus com baixo potencial ofensivo (adenovirus 26CoV2) para distribuir um gene que transporta o código genético da proteína $S$. As porções do DNA do adenovírus originais que possibilitam sua replicação em células humanas são excluídas previamente. Essas informações genéticas podem gerar um mRNA específico, que é transportada ao citoplasma e, ao invés de produzir partículas de adenovírus, passa a produzir proteína spike. Consequentemente, é desencadeada a produção de células T (CD4 e CD8), células citotóxicas, células plasmáticas, interleucinas e células $B$, que constituem as três respostas imunes primárias para bloquear a infecção (7).

A eficácia, em geral, manteve-se em torno de 66 a 72\%, com um período mínimo de 4 semanas após a aplicação de sua única dose, para a prevenção de doença moderada a grave, inclusive aqueles infectados com uma variedade emergente na época do estudo. Na África do Sul, local que há maior quantidade de variantes emergentes, os estudos apontam eficácia de 57\% (7). 


\section{REFERÊNCIAS BIBLIOGRÁFICAS:}

(1) Tregoning, J. S., Brown, E. S., Cheeseman, H. M., Flight, K. E., Higham, S. L., Lemm, N. M., ... \& Pollock, K. M. (2020). Vaccines for COVID-19. Clinical \& Experimental Immunology, 202(2), 162-192.

(2) Sociedade Brasileira de Pediatria. Vacinas COVID-19 - atualização. Soc Bras Pediatr. 2021;12

(3) Rawat, K., Kumari, P., \& Saha, L. (2020). COVID-19 vaccine: A recent update in pipeline vaccines, their design and development strategies. European journal of pharmacology, 173751.

(4) Li, Y. D., Chi, W. Y., Su, J. H., Ferrall, L., Hung, C. F., \& Wu, T. C. (2020). Coronavirus vaccine development: from SARS and MERS to COVID-19. Journal of biomedical science, 27(1), 1-23.

(5) Izda, V., Jeffries, M. A., \& Sawalha, A. H. (2020). COVID-19: A review of therapeutic strategies and vaccine candidates. Clinical Immunology, 108634.

(6) Robert-Guroff, M. (2007). Replicating and non-replicating viral vectors for vaccine development. Current opinion in biotechnology, 18(6), 546-556.

(7) Mascellino, M. T., Di Timoteo, F., De Angelis, M., \& Oliva, A. (2021). Overview of the Main Anti-SARS-CoV-2 vaccines: mechanism of action, efficacy and safety. Infection and Drug Resistance, 14, 3459. 


\section{Capítulo 3}

doi $10.37423 / 211105018$

\section{VACINAS DE RNA}

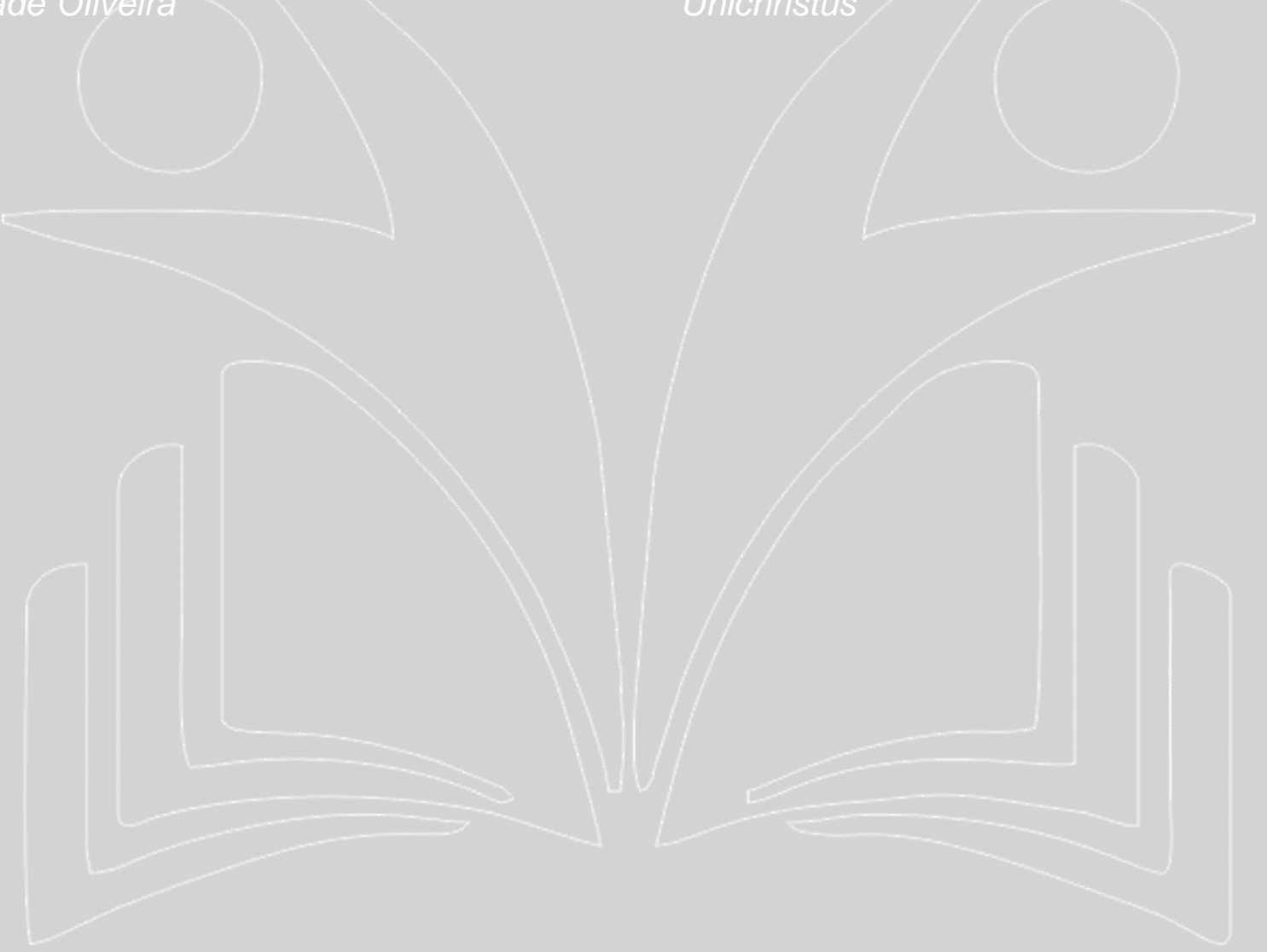


As vacinas de RNA são baseadas na premissa de carregar mensageiros que codificam antígenos virais, os quais podem ser traduzidos por células humanas para produzir proteínas antigênicas. Diferentemente da técnica de DNA viral, essas vacinas não necessitam passar pela fase de transcrição. No entanto, as vacinas provenientes de mRNA podem ter baixo potencial de imunogenicidade e tendência a se degradar, sendo essencial o uso de adjuvantes, como Advax, Alum, AS03 (GSK), MatrixM (Novavax), Cpg (Dynavax) e MF59 (CSL), uma vez que aumentam a resposta imune por meio de múltiplos mecanismos, causando um efeito de depósito, regulando a produção de quimiocinas e citocinas, aumentando o recrutamento celular para o local da injeção e aumentando a captação de antígeno e sua apresentação para células imunológicas específicas (1).

As vacinas baseadas em RNA não se integram ao genoma do hospedeiro, reduzindo, assim, o problema de toxidade genética. Além disso, comparadas a vacinas de vírus inativado ou com vetores vivos, apresentam chance reduzida de contaminação biológica durante a produção (2).

Em suma, os sistemas de entrega de vacina mRNA prontos para uso devem ser otimizados para:

1) Aumentar a estabilidade térmica da vacina com o fito de propiciar o armazenamento e o transporte à temperatura ambiente;

2) Proteger e embrulhar efetivamente o mRNA que codifica o antígeno;

3) Ser capaz de alcançar a produção em grande quantidade com controle de qualidade;

4) Possuir propriedades adjuvantes adequadas, induzindo à resposta imune celular e humoral contra uma variedade de patógenos (2).

Os principais fabricantes de vacinas de RNA contra o Sars-CoV-2 são as empresas Moderna e BioNTech / Pfizer (3). Essa classe de vacinas apresenta resposta imunológica aceitável, em média, a partir de 14 dias após a aplicação da primeira dose. No entanto, necessita de uma dose de reforço para a garantia de altos títulos de anticorpos neutralizantes e imunogenicidade a longo prazo (4).

Tais fatores propiciam às duas vacinas de mRNA serem candidatas ao às vacinas contra o novo coronavírus mais eficazes até hoje produzidas (3).

\section{MODERNA (MODERNA / NIAID):}

A vacina mRNA-1273 da Moderna codifica um trímero de pico de pré-fusão estabilizado, em que os aminoácidos em 986 e 987 foram substituídos por prolina para estabilizar a proteína de pico em sua conformação de pré-fusão. Além disso, os nucleotídeos do mRNA também foram modificados com o 
intuito de aumentar sua tradução e meia-vida e também de prevenir a ativação de genes associados ao interferon ao entrar na célula (5).

Em 16 de novembro de 2020, a Moderna expôs uma análise provisória de seu ensaio na fase III: seu resultado mostrou que dos participantes, 95 pacientes apresentaram COVID-19 sintomático, porém apenas 5 eram do grupo de mRNA-1273 - os casos restantes eram do grupo placebo, resultando em uma eficácia de aproximadamente 94,5\% (5). Acresça-se ainda, que 11 pacientes desenvolveram forma grave da doença, porém, nenhum deles fez o uso da vacina. Ademais, sua análise também não mostra nenhuma preocupação quanto à segurança, garantindo o uso eficaz dessa vacina como veículo de prevenção primária (5).

O perfil de imunogenicidade do mRNA 1273 é resultado de uma inovação de antígenos vacinais baseada em sua estrutura e acoplada a um forte sistema de entrega de nanopartículas de lipídios e o uso de nucleotídeos modificados, os quais evitam a ativação intracelular de interferons associados. Essas características foram relacionadas à ativação de células auxiliares foliculares $T$ específicas do antígeno e de células B do centro germinativo, bem como a uma expressão mais duradoura de proteínas (6).

\section{PFIZER INC./ BIONNTECH SE:}

A BioNTech, em associação com a Pfizer, desenvolveu vacinas à base de mRNA, conhecida como BNT162b2 a qual codifica uma proteína spike de comprimento total. Teve como base a vasta experiência da empresa alemã no desenvolvimento de terapêuticas baseadas nesse modelo, especialmente contra o câncer, usando moléculas RNA mensageiro modificadas e sistema de entrega intracelular (7).

Inicialmente, foram desenvolvidos 4 subtipos. No entanto, apenas BNT162b2 apresentou segurança associada à eficácia adequada. Um total de 43.548 participantes foram submetidos a randomização, dos quais 43.448 receberam injeções: 21.720 com BNT162b2 e 21.728 com placebo. Ao final, foi constatado que houve 8 casos de covid-19 com início após pelo menos 7 dias depois da segunda dose entre os participantes designados a receber a vacina original e 162 casos entre aqueles que receberam placebo, mostrando uma eficácia de 95\% na prevenção primária (8).

Entre aqueles que receberam a BNT162b2, a dor leve a moderada no local da injeção dentro de 7 dias após a aplicação foi a reação local mais comumente relatada, com menos de $1 \%$ dos participantes de todos os grupos relatando dor intensa e uma porcentagem bem menor que apresentou sinais 
flogísticos na região. O percentual de participantes com dor não aumentou após a aplicação da segunda dose. Além da dor, outros sintomas relatados com menor frequência foram fadiga e cefaleia. Os efeitos adversos foram mais relatados em pacientes mais jovens (16 a 55 anos) e mais frequentemente após a segunda dose aplicada (8). 


\section{REFERÊNCIAS BIBLIOGRÁFICAS:}

(1) Tregoning, J. S., et al. Vaccines for COVID-19. Clinical \& Experimental Immunology, 202(2), 162192, 2020.

(1) Park KS, Sun X, Aikins ME, Moon JJ. Non-viral COVID-19 vaccine delivery systems. Adv Drug Deliv Rev. 2021;169:137-51.

(2) Sax PE. Covid-19 vaccines - Frequently asked questions. N Engl J Med. 2021.

(3) Izda V, Jeffries MA, Sawalha AH. COVID-19: a review of therapeutic strategies and vaccine candidates. Clin Immunol. 2021;222:108634.

(4) Li YD, Chi WY, Su JH, Ferrall L, Hung CF, Wu TC. Coronavirus vaccine development: from SARS and MERS to COVID-19. J Biomed Sci. 2020;27(1):104.

(5) De Figueiredo, B. Q., et al. Vacinas de mRNA contra a Covid-19: aberta uma nova janela no campo da imunologia. Research, Society and Development, 10(10), 2021.

(6) Stadler, C.R., Bahr-Mahmud, H., Celik, L., Hebich, B., Roth, A.S. \& Roth R. P.(2017). Eliminação de grandes tumores em camundongos por anticorpos biespecíficos codificados por mRNA.Nat Med.23 (1), 815-817.

(7) Polack, F. P., et al. Safety and efficacy of the BNT162b2 mRNA Covid-19 vaccine. New England Journal of Medicine, 2020. 